\title{
SOME EFFECTS OF THE SECURITIES ACT UPON INVESTMENT BANKING PRACTICES
}

\author{
Grorge E. Bates*
}

The actual mechanism of investment banking, except for slight changes in form, has not been materially affected by the Securities Act of 1933. Examination of most of the apparent changes discloses that they are no more than continuations of trends commencing prior to 1933 or that they are adequately explained otherwise than by the Securities Act. Even were the Act aimed at producing an altered structure, it would be surprising to find that really basic changes had occurred during the initial period of adaptation.

Apart from technique, it can scarcely be denied that the Securities Act has promoted the exercise of greater care in the issuance of securities by investment bankers and officers of issuing corporations. There is no certainty that the Act has produced that result, for there were other factors in the aftermath of the nineteen-twenties that might well have had the same effect. It is perhaps true, also, that the Act has induced greater caution among those who offended least in the era which gave rise to the legislation, while it has had no comparable effect upon those who were reckless or less scrupulous.

In addition to a change of attitude, functional changes of real moment have been taking place in investment banking. For the most part, these relate to capital, real underwriting ability, markets, and "merchandise." Since they have been produced by causes other than the Securities Act they need not concern us here.

Experience under the Act may be divided into two periods: that before and that subsequent to the 1934 amendments. The earlier period is now only of academic interest. Extremists may claim that the original Act stifled most legitimate financing or that the lack of such security flotations during the period was entirely the result of other causes, but the truth undoubtedly lies somewhere between those views. It should be recognized that time is required for adjustment to any major legislative change. From the point of view of investment bankers it was fortunate that the law was introduced when the capital market was stagnant. As an aid to recovery it was unfortunate, for reopening of the legitimate capital markets was sorely desired, and even illegitimate financing might have been condoned as consistent with current

- A.B., 1923, A.M. 1924, University of Missouri; M.B.A., I925, Harvard University. Associate Professor of Investment Banking, Harvard Graduate School of Business Administration. Lecturer, Yale University School of L2w. Author of casebooks on investment banking and finance and contributor to legal and business periodicals. 
"boondoggling" and efforts at "pump priming," though the incidence of the supporting "tax" might have been less desirable. However this may have.been, those advocating such legislation were-between the horns of political expediency and economic desirability. It was possible to enact the statute during depression; probably impossible during prosperity. Considering that fact, among others, it was unfortunate that the Act should have been so drastic, but even this criticism is not a serious one in view of the promptness with which the law was amended. The amendments must share honors in the second period, moreover, with the improving and more discriminating administration of the Act.

It has been only in the two years 1935 and 1936 that there can be said to have been any real investment banking experience under that legislation. This is a short period for judging effects, and otherwise not a wholly satisfactory one because of the predominance of one class of security issues. For the most part the issues distributed by bankers have been bonds of institutional grade. A high proportion have been floated to refund previously outstanding issues. A sellers' market has existed for such securities, yields have been low, and gross underwriting and distributing spreads small. With a demand greater than the supply, the problem has been one of allotment rather than selling. Under such conditions one would not expect to find that the Securities Act had materially altered investment banking methods.

Where three years ago retail dealers and salesmen were acutely conscious of the Securities Act, today that Act seems to have been retired to the background where it is overshadowed by other problems. This is a normal and healthy condition if security dealers are likened to the good citizens who walk the streets without being made particularly aware of the penalties should they burglarize the houses they pass. To one who thinks of security dealers as undesirable citizens, on the other hand, it will presumably seem desirable that they be kept fully aware of the punishment they should incur.

The Act is brought home to dealers, however, in three other ways. Every effort is still made on every transaction to build a record which may be used as a defense in case of suit. Some houses have developed elaborate systems designed to this end, but there is already a tendency to drop them in favor of making a sale where there is conflict between the lawyer-designed protective devices and the judgment of the sales manager. The tendency to avoid "putting anything in writing," however, still persists.

"Beating the gun,"1 though not a new practice, has probably increased materially under the Act and in the current market. Since the "firm inquiries" of customers, or understandings between customers and salesmen as to retail allotments prior to the effective date, violate the spirit if not the letter of the waiting period provision, dealers find this one of the harassing features of the Act. They have little sympathy with the waiting period, for experience does not indicate that it is utilized by in-

\footnotetext{
1 "Beating the gun" is a trade term for selling, contracting to sell, or informally and orally promising to allot securities to a customer prior to the date stipulated for the public offering.
} 
vestors for study of new issues, while dealers are placed in the uncomfortable position of being "bootleggers" of popular issues when customers insist on being "kept in mind" for specific amounts of such new securities. The waiting period has neither removed nor seriously affected the opportunities for using high-pressure selling tactics. $^{2}$

Perhaps the greatest complaint of those directly charged with selling securities is that against the usual form of prospectus under the Act. They agree that the information it contains should be made available upon request, but they believe that most prospectuses go into the wastebasket because customers feel that they do not have the time to study them and to select from such a mass of information the points upon which their judgments should actually be based. Salesmen find that customers want a summary of the leading features of a security issue, and they feel that the typical prospectus does not provide this. They also believe that customers still rely to a considerable degree upon the judgment of the originating house (which presumably studies the security at first hand, with expert knowledge, and at greater length than could the average individual investor) and of the dealer who recommends the security to fit a particular investment need. The dealers' complaint seems to be well founded, but it is suggested that when originating houses find it necessary to sell securities, rather than merely take orders for them, they will devise more readable, attractive, and discriminating prospectuses. This tendency is already to be noted in a few instances where bankers have really tried to produce an informative selling document rather than a bulky folder containing nothing but an unimaginative recital of required facts.

In substance the method of underwriting and distributing securities at wholesale, known as syndication, has not been changed by the Act. Most of the minor changes which may be noted would have been produced by the nature of the market and the type of security sold during the period under consideration. Perhaps the Securities Act has discouraged use of the old type of selling syndicate, but the trend toward almost exclusive use of selling groups was well advanced prior to 1933 and had a substantial basis in changes which had taken place within the investment banking business. The growing distinction between underwriting and selling was adopted by the Act as a convenient division in imposing certain responsibilities. ${ }^{3}$ The application was thoroughly unrealistic, however, and from it arises one of the few instances in which there has been a tendency toward changing the structure of the investment banking process."

"See Bates, The Waiting Period Under the Securities Act (Jan. 1937) I5 Harv. Bus. Rev. 203.

"An exception to the broad definition of an underwriter (who may incur liability under $51 \mathrm{I}(\mathrm{a})(5)$ ) is made in $\$ 2$ (II) for "a person whose interest is limited to a commission from an underwriter or dealer not in excess of the usual and customary distributors' or sellers' commission."

"For the imposition of potential liabilities it would have been logical to have distinguished between originators and dealers. The underwriting function should not be involved. The effect of the distinction actually made has been to reduce the flexibility of syndication and to make underwriters underwrite not only market risks but also the liability risks under the Securities Act of originators and others. 
The number of retail dealers employed in syndication appears not to have changed greatly. It might seem that a greater than necessary number of retail outlets was used. With the large volume of refunding issues, however, the holders of the securities being refunded may have constituted the logical market. Dealers who participated in prior offerings by those issuers may consequently have been the best means for tapping that market. On the other hand, it is true that some of the popular issues might have been absorbed by a very few institutions which could have been reached without using an extensive dealer organization. An explanation is that the desire of issuers for broad distribution was sufficient to cause them to pay for that service. Some issuers, as well as most originating bankers, may have felt that it was incumbent upon them, too, to give business to the dealers at such a time so that they would be prepared to participate in distributing securities at another time when their services would be really needed.

The appearance of using a greater number of underwriters is explained by the fact that before 1933 it was usual to give publicity only to the names of the principal underwriters (participants in the group or groups nearest the original purchase or underwriting) while subsequently all names have appeared. The practical difficulties of having sub-underwriting under the Act, which does not distinguish among types of underwriters, has meant-that there has usually been but one class of underwriter, where formerly there were not infrequently several groups of underwriters employed on each issue. Small gross banking spreads on the low-yield securities distributed during the period would in any event have tended to reduce the number of groups used.

Reciprocity and retail distributing ability continue as important reasons for inviting houses to participate in underwriting. The importance of distributing the market risk is perhaps increased due to reduced investment banking capital. The same insurance principle dictates that risk of liability under the Securities Act should likewise be spread.

The former practice has been continued of providing for a trading account to be operated for the underwriters. The powers of account managers have tended to be more restricted than formerly, but this is explainable on other grounds than the Securities Act. Moreover, the accounts have been much less active, and in many instances not used, either because circumstances did not demand it or because so much uncertainty surrounded the propriety of those transactions. Bankers have felt less restricted in trading account transactions in unlisted securities, but the ambiguity of Section 9(a) (6) of the Securities Exchange Act relative to "pegging, fixing, or stabilizing" in view of the prohibitions and perhaps conflicting requirements of Section 9 (a) (2) of that Act, particularly in the absence of rulings by the Commission, has tended to reduce such operations in listed securities to a minimum. As indicated, most of the problems arise from the Securities Exchange Act rather than the Securities Act. The principal unsolved problem under the latter involves the matter of disclosure. Disclosure of the trading account provisions must be made in 
the registration statement. The question is whether similar disclosure will suffice in a prospectus used after the date on which the trading account began or might be presumed to have begun to operate. For example, might the fact of maximum use of the trading account for supporting the market be a material fact under Section I2(2) which should have been stated in order to have made the bare statement that a trading account might operate not misleading? In other words, if the activity of the trading account is an index of market reception, it might be considered a material fact on which an investor might base his judgment. The reductio ad absurdum, of course, is that this view might require the affixing of stickers to prospectuses showing up-to-the-minute changes in the trading account position. Furthermore, the fundamental fact is reception of the issue by investors, not merely trading account activity. Carried to its logical conclusion this line of argument would develop the necessity for current disclosure of the volume of initial and secondary retail sales, as well as the amounts of repurchases. Under the requirements of Section ro, however, the prospectus need not refer to the state of retail sales, and in fact could not, for it is based upon the registration statement which is filed prior to the offering. Since no statement with respect to retail sales would be gratuitously made in the prospectus, the failure to make any disclosure of current market reception would not be apt to make misleading any statement made in the prospectus. Perhaps an answer to the problem is to be found in the word "material": substantial changes in the position of the trading account from that which the prospective buyer might assume to exist might be disclosed in the prospectus. ${ }^{5}$

Three effects upon the form of doing business may be noted. All underwriters now contract severally with the issuer. Fear of liabilities to be incurred through making selling group members agents of the underwriters in distributing securities has led underwriters to sell to the selling group members and pay an added transfer tax, though reserving from their own underwritings the amounts of securities they themselves wish to retail. Instead of receiving compensation for their services in the form of purchase group participations, there is a tendency for originators to take this compensation in the form of a fee from the underwriters.

While the Securities Act did distinguish, in the imposition of liability, between the underwriting and selling functions it drew no similar line between originating (the negotiation, -investigation, and preparation of a security issue) and underwriting. Theoretically, the duties and correlative liabilities imposed upon underwriters should have been placed upon originating houses alone. ${ }^{6}$ Presumably it failed to make this distinction because to have done so might have opened an attractive loophole for evasion. There may have been the thought, also, that placing liability on a greater number of persons would better protect the investor. Practically, however, there is a sound economic basis for division of labor between the originating house or houses and other underwriters. ${ }^{7}$ The practice of only originating houses actually

\footnotetext{
${ }^{8}$ Insofar as listed securities are concerned, the ultimate solution may lie with regulations of the Commission under $\$ 9(a)(6)$ of the Securities Exchange Act. 'Sce note 4, supra.

'See Douglas and Bates, The Federal Securities Act of 1933 (1933) 43 YAle L. J. 171, at 198 ef seg.
} 
investigating as well as performing the other originating functions has therefore continued as before. Since other underwriters must share in liabilities under the Securities Act, however, if they are unable to sustain the burden of proof provided in Section $\mathrm{II}^{8}$ non-originating underwriters have generally adopted the practice of going through certain formal motions designed for their protection. Akin to the efforts of dealers to "build a record" to protect them on their retail transactions is the somewhat ludicrous picture of partners or perhaps office boys representing the ten, twenty, or more underwriters meeting in solemn session to "investigate" the accuracy and sufficiency of the registration statement by having it read to them by counsel. When a law demands the impracticable it is not surprising to find business men performing rituals which are apt to be meaningful only to lawyers.

A salient effect of the Act has, as previously noted, undoubtedly been the care it has induced in the origination of securities. One of the best protections against suit under the Act is probably avoidance of those types of security issues which are apt to generate them. The period under review, however, scarcely provides a test of this. Able originators make painstaking investigations of their security issues independent of their investigation of, and only partially based upon, the facts in the registration statement. Some foresee the danger, though, that investment bankers may be indirectly encouraged by the Securities Act to think only in terms of legal liabilities and so to abdicate their business judgment of a security in favor of counsels' opinion that a registration statement is safe.

Originators are indebted to the Securities Act as an "open sesame" to facts respecting issuing companies to which they formerly did not have access or which they were not allowed to make public. Haggling over such matters is now usually ended by the bankers' statement that the information is required by the Securities Act. The banker can thus gain access to all the facts at the command of the issuer, though the struggle respecting wider publicity is not entirely ended. The issuer may wish to file under confidential cover certain required information, such as that pertaining to sales, cost of sales, contracts, and subsidiaries. ${ }^{\ominus}$

It seems not to have been anticipated at the passage of the Act that the waiting period would have the effect of partially defeating its own end by causing underwriters to postpone taking commitments until the end of the period. The result of this postponement has been to delay the issuance of definitive prospectuses so greatly that investors can gain little direct benefit from the "cooling period."10 . Underwriting commitments are being made as far in advance of actual offerings as before r933,

- Section II (a) of the Securitics Act designates those who may be held civilly liable for untrue statements or omissions to state material facts in registration statements. Section 11 (b) provides certain defenses to persons "other than the issuer," the burden of proof being placed on the defendant. For example, as to certain portions of the registration statement, a defendant may prove as a defense that "he had, after reasonable investigation, reasonable ground to believe, and did believe, at the time such part of the registration statement became effective, that the statements therein were true and that there was no omission to state a material fact required to be stated therein or necessary to make the statements therein not misleading."

- Nice questions of whether such information should be made public are continually presented to the Commission for determination.

${ }^{10}$ Note 2, supra. 
but there has been no tendency for commitments to be taken at the beginning of the waiting period, i.e., twenty days before the normal effective date. Market risks would be greatly increased, as well as risks that the waiting period would exceed twenty days.

Market conditions since 1933 have encouraged the practice of selling without commitment or of hedging commitments with more elaborate clauses giving bankers the option of withdrawing in the event of adverse market, political, company, or catastrophic changes. To these latter has been added a further provision relieving bankers of their commitments in the event that a stop order is issued by the Commission or if proceedings are commenced. The latter clause frequently is effective to the date for payment and delivery, rather than merely to the date of public offering. The various factors making for uncertainty, among them the Securities Act, have certainly made for elaboration and more extensive use of these clauses, but it is not unlikely that those primarily caused by factors other than the Securities Act will vary in use according to current estimates of such factors. As to liability under the Securities Act, it has become the common practice for bankers to contract with issuers that the latter shall hold them harmless on all suits, usually but not always excepting suits with respect to statements which the bankers supply. Similar contracts with issuers by directors and others made liable are also common. This may represent no material increase in liability for issuers, since they do not share in the defenses accorded others made liable under Section II. A variety of contracts has also been aimed at apportioning liability among the many persons contingently made liable, since the Act failed to clarify this problem.

Where public offering through investment bankers has been made of securities (other than state and municipal obligations) exempt from the registration requirement, the provisions of Section 12(2) of the Securities Act have made necessary in most cases the preparation of a prospectus fully equivalent to that required under Section ro for registered securities. The alternative to full disclosure is probably the giving of only the name and price of the security offered.

A fairly large number of security issues has been privately placed rather than publicly offered. There is as yet no certainty respecting what constitutes a public offer, but it has been variously interpreted that an offer to not more than three, five, eight, ten, twelve, fifteen, or twenty specific persons is not a public offer. Some have also interpreted the term relative to the number of persons to whom the security is eventually sold. ${ }^{11}$ Investment bankers have played a part in such offerings, acting in the capacity of agents for the issuer in making the private offering. Apart from costs of registration, there have at times been real savings in private placement. The possibility open to issuing companies of directly placing high-grade institutional securities privately has provided leverage for the reduction of banking spreads. Some agency positions may have been taken by bankers at almost nominal commissions to prevent business from leaving their hands entirely. From the standpoint of the

in For example, some are of the opinion that sale should be to not more than five persons, but that the offer may be made to as many as twelve.

The circumstances of the offering are probably more important than the mere number of those solicited, but practically bankers are apt to think primarily in concrete terms such as specific numbers. 
issuer the choice rests largely with the sort of market desired or necessary and the relative costs. Registration expenses, both direct and indirect, and risks of suits are counted among those costs. In an earlier stage of experience with the Act and under market conditions then prevailing it was often cheaper to place securities privately. More recently the cost factors, considering prices obtainable in the two markets, have been more evenly balanced. Market factors have therefore more frequently turned the scales in favor of public offerings. In the public offerings, too, there is sometimes less dictation of restrictive provisions than issuers met in dealing directly with investing institutions. The mere fact of disclosure, itself, seems to have been a minor factor in the decisions. ${ }^{12}$

Originators and registrants still complain that registration statement questionnaires are ill adapted to the requirements of specific situations. To some extent this will always be inevitable, but great advances have been made over the registration forms first issued and further improvement may be anticipated as forms are developed to meet a wider range of circumstances. ${ }^{13}$ Perhaps it is such a fault of the present regulations which gives rise to the issuance by the Commission of so many deficiency letters. ${ }^{14}$ Many bankers seem to believe, however, that the additional information requested on nearly every statement is commonly frivolous and seldom material to the investment and so constitutes merely bureaucratic operation beyond the intent of the Act. ${ }^{15}$ It would not be surprising if this were to a certain extent true, as is likewise often found in the public contacts of other governmental agencies and as it is in the operation of internal controls of large business corporations. The only serious question it raises, beyond that of administrative efficiency (which it may be hoped will continue to improve), is the extent to which administrative controls should be applied under tile present form of the Securities Act.

Much credit must be given to those administering the Act for the fact that there has been so little interference with legitimate investment banking operations. Despite its having been burdened with two other major responsibilities, ${ }^{16}$ the Commission has achieved an outstanding administrative record among New Deal agencies. The magnitude of the present investigatory, administrative, and quasi-judicial tasks can scarcely have been visualized by those responsible for the legislation. It is hoped that this success will not lead to imposing still further tasks upon the Commission which would almost inevitably lead to impaired efficiency. It is still more to be hoped that this Commission will continue to attract and hold able personnel. The powers and responsibilities with which it is entrusted are now so great that the danger of a lowering rather than rising standard of administrative ability is a matter for grave concern.

${ }^{12}$ It should be noted that a number of essentially private offerings have been registered.

${ }^{13}$ There is a danger that the new forms may do no more than add requirements to the present ones.

"Ietters from the Commission requesting that registration statements or prospectuses be amended to include other or further information are commonly called "deficiency letters."

${ }^{25}$ Further complaint is directed to the last minute reversals of opinion as to the sufficiency of statements. When questions are involved which do not appear to be really material and the changes cost several thousand dollars the complaint is apt to be particularly bitter.

${ }^{10}$ The Securities Exchange Act of 1934 and The Public Utilities Holding Company Act. 